\title{
Use of Fish Larva Morphometry to Predict Exclusion Capabilities of Small-Mesh Screens at Cooling-Water Intakes
}

\author{
Philip J. Schneeberger and David J. Jude \\ Great Lakes Research Division, Institute of Science and Technology \\ University of Michigan, Ann Arbor, Michigan 48109
}

\begin{abstract}
A relationship between total lengths and body depths of certain fish larvae was used to predict the effectiveness of small-mesh screens in limiting entrainment of fish larvae at cooling-water intakes. Total length-body depth regressions were linear for eight species (293 larvae) common to Lake Michigan near the J. H. Campbell Power Plant at Port Sheldon, Michigan. Regressions indicated that 35-100\% (depending on species) of the fish larvae that had been entrained by the J. H. Campbell Plant in 1978 would have been excluded if $0.5-\mathrm{mm}$ mesh screening had been employed in the plant's cooling water intake system instead of 9.5-mm bar mesh vertical traveling screens. "1 these calculations do not take into consideration approach velocities of intake water, larva avoidance behavior, or mortality due to impingement on or extrusion through the screens.
\end{abstract}

Water drawn from aquatic systems and used for once-through cooling in power plants sometimes contains large numbers of fish larvae. Small-mesh screening $(0.5-2.0 \mathrm{~mm})$ employed at cooling water intakes is one larva-exclusion system that has drawn attention from several investigators (Tomljanovich et al. 1977; Cheesman and Cheesman 1978; Hanson et al. 1978; Magliente et al. 1978; Murray and Jinnette 1978; Musalli et al. 1978; Gulvas and Zeitoun 1979) and institutions (United States Environmental Protection Agency 1976; Oak Ridge National Laboratory 1979), and that has been examined in workshops and symposia.

Effectiveness of small-mesh screens as a larva-exclusion system depends in part on body dimensions of larvae in relation to screen sizes. Of various body measurements, length data occur most frequently in the literature. However, Tomljanovich et al. (1977) state that because of vast differences in body shapes, body length alone is not a good indicator of percent retention on fine-mesh screens; cross-sectional dimensions generally are superior to total length for predicting potential entrainment. Here we establish a relationship between total length and body depth of larvae in a first attempt to assess usefulness of this relationship to predict larva exclusion from small-mesh screens at intakes.

\section{Methods}

Total lengths (TL), body depths, and body widths were measured for certain species of larval fishes (defined as any fish less than $25.4 \mathrm{~mm}$ ) common to Lake Michigan near the $\mathrm{J}$. $\mathrm{H}$. Campbell Power Plant, Port Sheldon, Michigan. Species included alewife (Alosa pseudoharengus); common carp (Cyprinus carpio); Cottus spp.1; johnny darter (Etheostoma nigrum); rainbow smelt (Osmerus mordax); spottail shiner (Notropis hudsonius); trout-perch (Percopsis omiscomaycus); and yellow perch (Perca flavescens). Specimens were obtained from the Great Lakes Regional Fish Larvae Collection housed at the Great Lakes Research Division, University of Michigan (see Dorr and Jude, in press) and from larvae collected in nets towed in Lake Michigan between 1973 and 1979 near the J. H. Campbell and D. C. Cook power plants (Jude et al. 1975; Jude et al. 1978; Jude, et al. 1979; Jude et al. 1979). All larvae were preserved in a $5 \%$ buffered formaldehyde solution. Shrinkage of larvae due to formaldehyde preservation was found to be only $3.8 \%$ by both Toetz (1966) and Sameoto (1971).

Total length and body depth (measured at the point of greatest depth, including yolk sac)

\footnotetext{
${ }^{1}$ With taxonomic keys available during this study, it was not possible to distinguish between larvae of two sculpirn species (Cottus cognatus and Cottus bairdi) found near the J. H. Campbell Plant.
} 

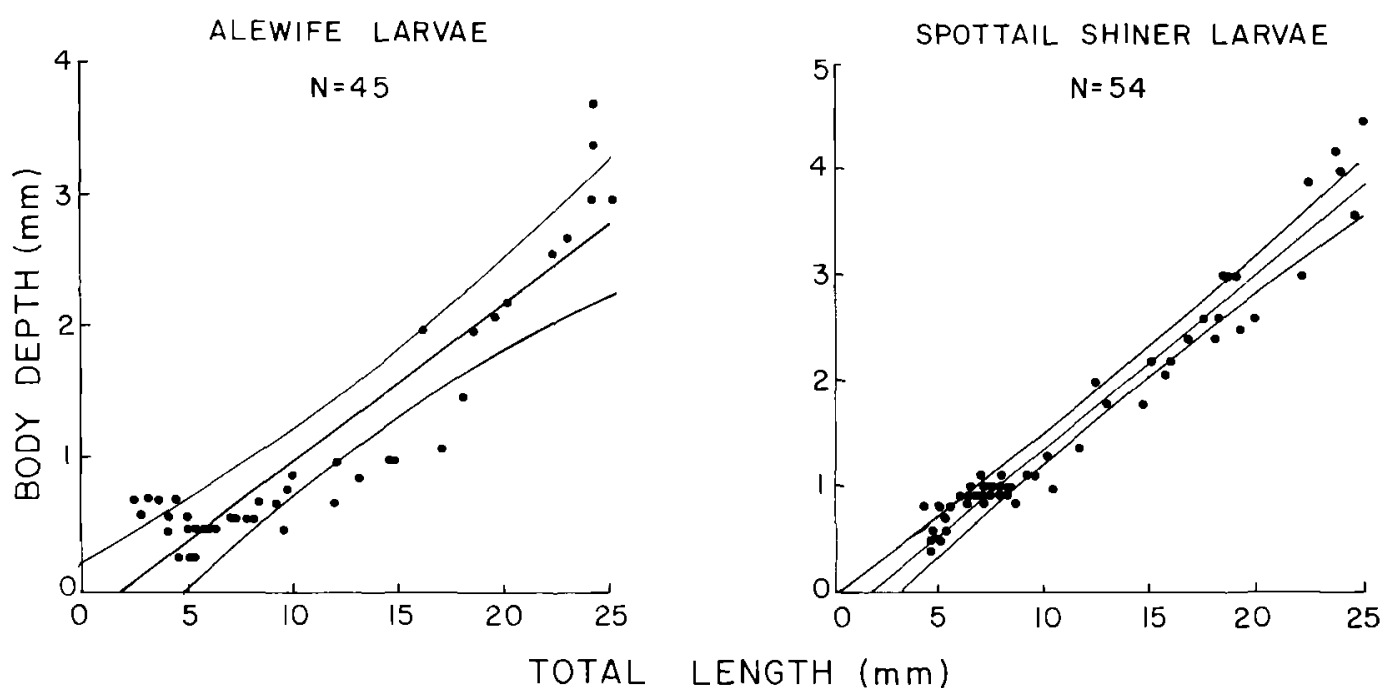

FIGURE 1.-Scatter plots, regression lines, and $95 \%$ confidence bands for total lengths and body depths of two species of fish larvae from Lake Michigan.

of each larva were measured to the nearest 0.1 $\mathrm{mm}$ under a $10 \times$ binocular microscope. Body widths were measured for representative numbers of larvae and in all cases body depth equalled or surpassed body width. Body depth, therefore, was used for our analyses. Tomljanovich et al. (1977) also found that for all species used in their study, mean depth was equal to or greater than mean width. Scatter plots and simple linear regressions for body depth versus total length were generated by the Michigan Interactive Data Analysis System (Fox and Guire 1973). Ninety-five percent confidence bands were calculated and plotted for regression lines.

Regressions were used to calculate total lengths of larvae corresponding to body depths of $0.5,1.0$, and $2.0 \mathrm{~mm}$ for each species. These lengths were then compared to cumulative length frequencies for some of the most common larvae entrained during 1978 at the Campbell Plant. Entrainment sampling at Campbell was conducted with a $363-\mu \mathrm{m}$ mesh plankton net suspended in the plant's discharge canal. Larvae were measured to the nearest 0.1 $\mathrm{mm}$ and entrainment estimates were generated based on sample densities and total flow through the plant (see Jude et al. 1978 for details). From these comparisons, we estimated the percentage of fish larvae that could have been either passed or retained by $0.5-, 1.0-$, and 2.0-mm mesh screens.

\section{Results}

Of eight species analyzed, alewife, common carp, rainbow smelt, spottail shiner, and yellow perch were among the fish most frequently entrained at the J. H. Campbell Plant by the existing cooling water intake, which draws water from Lake Michigan and Pigeon Lake. Cottus spp., johnny darter, and trout-perch are additional species potentially susceptible to entrainment when offshore intakes become fully operational in 1981.

Alewife (Fig. 1), common carp, rainbow smelt, spottail shiner (Fig. 1), trout-perch, and yellow perch all showed linear relationships between total length and body depth with high coefficients of determination $\left(R^{2} \geqslant 0.85\right.$ : Table 1). High coefficients of determination, low mean-square errors, and narrow confidence intervals are evidence of the high correlation and good predictive relationship between total length and body depth. Small larvae of Cottus spp. (Fig. 2) and, to a lesser extent, johnny darter showed nonlinear total length-body depth relationships due to the presence of a sizable yolk sac. As the yolk sac was absorbed, body depth decreased as length increased. After yolk-sac absorption, body depth increased with length, as with other species; consequently, the relationship became linear (Table 1, Fig. 2).

Alewife and rainbow smelt were two of the most frequently entrained species at the Campbell Plant. Newly hatched alewives entrained in 

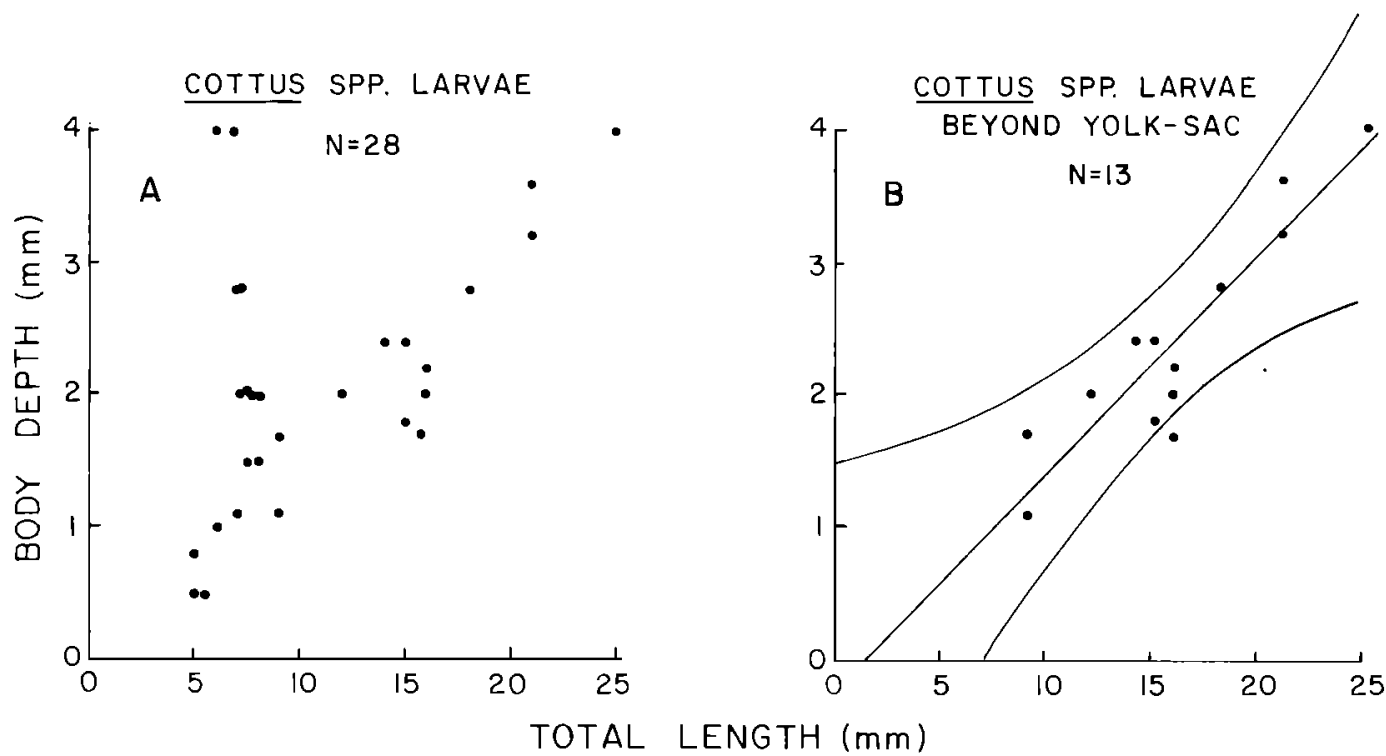

FIGURE 2.-Relationship between body depth and total length for Cottus spp. found in Lake Michigan. (A) Scatter plot of all available data. (B) Scatter plot, regression line, and $95 \%$ confidence bands for the total length-body depth relationship excluding fish with yolk sacs.

May, June, and July 1978 at the Campbell Plant could pass through a $0.5-\mathrm{mm}$ mesh screen ( $\mathrm{Ta}$ ble 2). Of a projected 211,000 alewife larvae entrained in May, we estimate that only $27 \%$ would have been large enough to be excluded by a $0.5-\mathrm{mm}$ mesh screen, and mesh screens of 1.0 and $2.0 \mathrm{~mm}$ may not have excluded any alewife of this early life stage (Table 3 ). Protection for only $18 \%$ of the estimated 3.17 million alewife larvae entrained in June would have

TABLE 1.-Summary of linear regressions of total length versus body depth for common Lake Michigan larval fishes. $\mathbf{R}^{2}$ $=$ coefficient of determination, $\mathrm{Y}=$ body-depth axis.

\begin{tabular}{|c|c|c|c|c|c|c|c|c|}
\hline Species & $N$ & $\begin{array}{c}\text { Total } \\
\text { length range } \\
\text { measured } \\
(\mathrm{mm})\end{array}$ & $\begin{array}{c}\text { Body } \\
\text { depth range } \\
\text { measured } \\
(\mathrm{mm})\end{array}$ & $\begin{array}{c}\text { Hatching } \\
\text { length } \\
\text { (mm) }\end{array}$ & Slope & $\begin{array}{c}Y- \\
\text { intercept }\end{array}$ & $R^{2}$ & $\begin{array}{l}\text { Mean- } \\
\text { square } \\
\text { error }\end{array}$ \\
\hline Alewife & 45 & $2.5-25.0$ & $0.3-3.7$ & $2.5^{a}$ & 0.12 & -0.19 & 0.85 & 0.13 \\
\hline Common carp & 29 & $3.5-24.5$ & $0.3-4.8$ & $3.0-6.4^{\mathrm{b}}$ & 0.21 & -0.43 & 0.88 & 0.13 \\
\hline Cothus spp. ${ }^{\circ}$ & 28 & $5.0-25.0$ & $0.5-4.0$ & $6.0-7.0^{\mathrm{d}}$ & 0.09 & 1.12 & 0.26 & 0.78 \\
\hline Cottus spp. ${ }^{\mathrm{e}}$ & 13 & $9.0-25.0$ & $1.1-4.0$ & & 0.16 & -0.21 & 0.83 & 0.13 \\
\hline Johnny darterc & 30 & $3.0-25.0$ & $0.6-3.9$ & $5.0^{r}$ & 0.13 & 0.24 & 0.85 & 0.15 \\
\hline Johnny darter & 19 & $7.2-25.0$ & $0.7-3.9$ & & 0.16 & -0.39 & 0.92 & 0.07 \\
\hline Rainbow smelt & 35 & $4.0-25.0$ & $0.2-2.7$ & $4.1-6.0^{g}$ & 0.10 & -0.20 & 0.89 & 0.07 \\
\hline Spottail shiner & 54 & $4.3-24.9$ & $0.4-4.5$ & $4.3-6.1^{\mathrm{h}}$ & 0.17 & -0.28 & 0.95 & 0.06 \\
\hline Trout-perch & 21 & $4.5-25.0$ & $0.6-4.5$ & $5.3-6.0^{\mathrm{i}}$ & 0.19 & -0.21 & 0.97 & 0.05 \\
\hline Yellow perch & 51 & $4.8-25.0$ & $0.5-3.8$ & $4.8-6.0^{j}$ & 0.17 & -0.29 & 0.95 & 0.05 \\
\hline \multicolumn{9}{|c|}{ 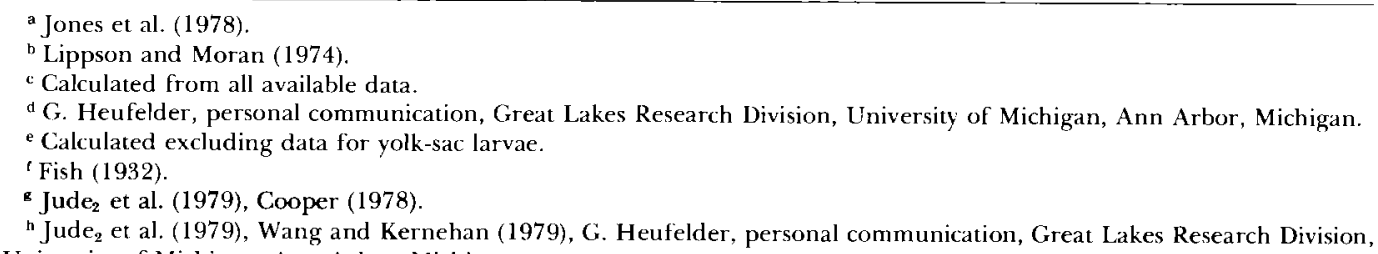 } \\
\hline
\end{tabular}


TABLE 2.-Total length in millimeters at which common Lake Michigan larval fish would attain a body depth of $0.5,1.0$, and $2.0 \mathrm{~mm}$. Total-length values were obtained from regression equations.

\begin{tabular}{lccc}
\hline & \multicolumn{3}{c}{ Body depth (mm) } \\
\cline { 2 - 4 } \multicolumn{1}{c}{ Species } & 0.5 & 1.0 & 2.0 \\
\hline Alewife & 5.8 & 9.9 & 18.2 \\
Common carp & 4.4 & 6.8 & 11.6 \\
Cottus spp. $^{\mathrm{a}}$ & $\mathrm{b}$ & $\mathbf{b}$ & 13.6 \\
Johnny darter $^{\mathrm{a}}$ & $\mathbf{b}$ & 8.4 & 14.5 \\
Rainbow smelt $_{\text {Spottail shiner }}$ & 6.9 & 11.9 & 21.8 \\
Trout-perch & 4.7 & 7.7 & 13.7 \\
Yellow perch & 3.8 & 6.4 & 11.7 \\
\hline
\end{tabular}

a Calculated from fish without yolk sacs.

${ }^{b}$ Predicted lengths from the regression equation are not valid because yolk-sac larvae were deleted.

been provided by a $0.5-\mathrm{mm}$ screen. Numbers of entrained alewife were greatest in July (16.7 million) and August (16.5 million); predicted percentages of exclusion by 0.5 - and $1.0-\mathrm{mm}$ mesh screens increased somewhat (15-33\%) during these months due to larva growth. However, not until September, when 232,000 alewife larvae were entrained, was $100 \%$ exclusion predicted if $0.5-$ or $1.0-\mathrm{mm}$ mesh screens had been employed.

Eighty-five percent of a projected 989,000 entrained rainbow smelt larvae, newly hatched in May, could have passed through $0.5-\mathrm{mm}$ mesh screens, but rapidly growing smelt larvae would have become increasingly less susceptible to entrainment through small-mesh screens in later months (Tables 2, 3). By June, $46 \%$ of 496,000 entrained smelt larvae, and all the rainbow smelt entrained in July $(35,100)$ and August $(7,630)$, could have been excluded by a $0.5-\mathrm{mm}$ mesh screen.

Other species for which length-frequency data were available (common carp, spottail shiner, and yellow perch) would theoretically have been almost totally protected from entrainment by a $0.5-\mathrm{mm}$ mesh screen during all months in 1978 (Table 3). Minnow larvae less than $9.0 \mathrm{~mm}$ were difficult to identify positively, but if all unidentified minnow larvae that were entrained at the J. $\mathrm{H}$. Campbell Plant in 1978 were assumed to be spottail shiners in calculations, the predicted exclusion by $0.5-\mathrm{mm}$ mesh screens would have been $85 \%$ in May and higher in subsequent months.

\section{Discussion}

Estimates of exclusion were made on the assumption that fish larvae pass through screens lengthwise and that larvae with body depths equal to mesh size would be excluded. Other factors must be considered, however. For example, Tomljanovich et al. (1977) found that in some cases, depending in part on approach velocity of intake water, fish with body depths

TABLE 3.-Percentages of some common Lake Michigan fish larvae entrained at the J. H. Campbell Plant that could be excluded by 0.5-, 1.0-, and 2.0-mm mesh screens. Percentages were calculated from 1978 length-frequency entrainment data. Blank spaces represent no data.

\begin{tabular}{|c|c|c|c|c|c|c|c|c|c|}
\hline \multirow[b]{2}{*}{ Species } & \multirow{2}{*}{$\begin{array}{c}\text { Mesh size } \\
\quad(\mathrm{m}, \mathrm{m})\end{array}$} & \multicolumn{7}{|c|}{ Month } & \multirow{2}{*}{$\begin{array}{c}\text { All } \\
\text { months } \\
\text { combined }\end{array}$} \\
\hline & & May & Jun & Jul & Aug & Sep & Oct & Nov & \\
\hline \multirow[t]{3}{*}{ Alewife } & 0.5 & 27 & 18 & 21 & 33 & 100 & 100 & 100 & 35 \\
\hline & 1.0 & 0 & 4 & 15 & 16 & 100 & 100 & 100 & 24 \\
\hline & 2.0 & 0 & 0 & 0 & 7 & 97 & 88 & 86 & 13 \\
\hline \multirow[t]{3}{*}{ Common carp } & 0.5 & 100 & 99 & 100 & 100 & & & & 99 \\
\hline & 1.0 & 45 & 59 & 18 & 0 & & & & 41 \\
\hline & 2.0 & 0 & 0 & 0 & 0 & & & & 0 \\
\hline \multirow[t]{3}{*}{ Rainbow smelt } & 0.5 & 15 & 46 & 100 & 100 & & & & 29 \\
\hline & 1.0 & 0 & 17 & 87 & 100 & & & & 9 \\
\hline & 2.0 & 0 & 1 & 24 & 100 & & & & 1 \\
\hline \multirow[t]{3}{*}{ Spottail shiner } & 0.5 & & 100 & 100 & 100 & & & & 100 \\
\hline & 1.0 & & 100 & 100 & 100 & & & & 100 \\
\hline & 2.0 & & 0 & 0 & 0 & & & & 0 \\
\hline \multirow[t]{3}{*}{ Yellow perch } & 0.5 & 99 & 100 & 100 & & & & & 99 \\
\hline & 1.0 & 13 & 36 & 42 & & & & & 14 \\
\hline & 2.0 & 0 & 0 & 0 & & & & & 0 \\
\hline
\end{tabular}


up to $84 \%$ greater than mesh size could be compressed and extruded through the mesh. Furthermore, larva avoidance behavior could greatly influence entrainment rates. Hanson et al. (1978) observed screen avoidance by aquaria-held striped bass (Morone saxatilis) larvae $(5.2-9.2 \mathrm{~mm})$ in all experiments. Using smallmesh screens on pumps in Lake Michigan, Gulvas and Zeitoun (1979) found that field-larva densities (plankton-net data) were much greater than entrained-larva densities (as measured through a pump). Differences in densities were attributed to screen avoidance behavior by most species. In the same study, however, some species (minnows, darters, sculpins, and troutperch) were attracted to structures presumably for cover or nesting; these species (and their eggs) were entrained at higher rates than would be expected from field density data.

Before fine-mesh screens become a biologically acceptable alternative to conventional traveling screens, it must be shown that mortality rates of larval fish impinged on fine-mesh screens are significantly lower than mortality rates of entrained larvae. Such data are scant or nonexistent (Fritz 1980). Some of the most important factors influencing postimpingement survival include impingement duration, fish size, and approach velocity (Tomljanovich et al. 1977). Impingement mortality is site- and species-specific and must be determined from in situ studies during plant operations (Oak Ridge National Laboratory 1979). One solution to mitigate impingement losses of larvae involves a system in which a water spray gently dislodges larvae from small-mesh screens and carries them by a trough back to water where the larvae may survive (Magliente et al. 1978).

Due to many complicating factors, our predictions of exclusion based on larval total length-body depth regressions probably have wide limits. However, such predictions are useful for comparing relative exclusion effectiveness of different screen mesh sizes. Preferential protection of certain sizes of larvae should be considered because as size increases, larvae become relatively less susceptible to entrainment (Jude et al. 1978) and for several taxa of larvae that were experimentally impinged on screens, long-term survival increased with larval length (Tomljanovich et al. 1977). Larger larvae also have higher natural survival rates; therefore, their losses have stronger ecological implica- tions for the population than would loss of newly hatched larvae. Therefore, it may be efficacious (considering also operational costs and clogging problems of small-mesh screens) to preferentially protect larger larvae from entrainment by determining screen mesh sizes that, when employed, would exclude large larvae and entrain small ones. Size-specific spatial and temporal distribution of larvae, and their densities and survival rates, would have to be known for calculation of projected population effects brought about through size-selective protection of larvae. Small-mesh screens then could be employed during certain months of the year when larvae of the size determined to require protection are present in large numbers; screen removal may be appropriate during months when larvae are less abundant.

\section{Acknowledgments}

This study was supported in part by the Environmental Services Department of Consumers Power Company, Jackson, Michigan. Within the Great Lakes Research Division, University of Michigan, we thank Charles Madenjian for his statistical work, and Paul Rago, Frank Tesar, George Heufelder, and John Dorr III for their helpful reviews of this manuscript. Referees Ron Kernehan and B. N. Hanson provided helpful and critical reviews. Jim Wojcik, Debbie Brooker, Laura Black, and June Huhn measured some of the larvae used in these calculations. Loren Flath drafted figures and Jan Farris typed the manuscript.

\section{References}

Chefsman, W. D., and R. R. Cheesman. 1978. Larval exclusion with woven-slot, fine-mesh screening. Pages 89-90 in R. K. Sharma and J. B. Palmer, editors. Larval exclusion systems for power plant cooling water intakes. Argonne National Laboratory, Argonne, Illinois, USA.

Cooper, J. E. 1978. Identification of eggs, larvae, and juveniles of the rainbow smelt, Osmerus mor$d a x$, with comparisons to larval alewife, Alosa pseudoharengus, and gizzard shad, Dorosoma cepedianum. Transactions of the American Fisheries Society 107:52-62.

DoRr, J. A., III, AND D. J. JudE. In press. Organization and status of a cooperative Great Lakes regional fish larvae collection. Journal of Great Lakes Research.

Dorr, J. A., III, D. J. Jude, F. J. Tesar, And N. J. IHURBre. 1976. Identification of larval fishes taken from the inshore waters of southeastern Lake Michigan near the Donald C. Cook Nuclear 
Plant, 1973-1975. Pages 61-82 in J. Boreman, editor. Great Lakes fish egg and larvae identification; proceedings of a workshop. United States Fish and Wildlife Service, FWS/OBS-76.23, Ann Arbor, Michigan, USA.

FISH, M. P. 1932. Contributions to the early life histories of sixty-two species of fishes from Lake Erie and its tributary waters. United States Bureau of Fisheries Bulletin 47:293-398.

Fox, D. J., AND K. E. Guire. 1973. Documentation for MIDAS (Michigan Interactive Data Analysis System), 2nd edition. Statistical Research Laboratory, University of Michigan, Ann Arbor, Michigan, USA.

Fritz, E. S. 1980. Cooling water intake screening devices used to reduce entrainment and impingement. United States Fish and Wildlife Service, FWS/OBS-76/20.9, Ann Arbor, Michigan, USA.

Gulvas, J. A., And I. H. Zertoun. 1979. Cylindrical wedge-wire screen investigations in offshore Lake Michigan for the J. H. Campbell Plant, 1979. Pages 39-46 in Passive intake screen workshop. Johnson Division VOP, Surface Water Screen Department, New Brighton, Minnesota, USA.

Hanson, B. N., W. H. Bason, B. E. Beitz, and K. E. Charles. 1978. Practicality of profile-wire screen in reducing entrainment and impingement. Pages 195-234 in R. K. Sharma and J. B. Palmer, editors. Larval exclusion systems for power plant cooling water intakes. Argonne National Laboratory, Argonne, Illinois, USA.

Jones, P. W., F. D. Martin, and J. D. Hardy, JR. 1978. Pages 89-97 in Development of fishes of the mid-Atlantic bight: an atlas of egg, larval and juvenile stages, volume 1. United States Fish and Wildlife Service, FWS/OBS-78/12, Washington, District of Columbia, USA.

Jude, D. J., B. A. Bachen, G. R. Heufelder, H. T. Tin, M. H. Winnell, F. J. Tesar, AND J. A. DorR III. 1978. Adult and juvenile fish, ichthyoplankton and benthos populations in the vicinity of the J. H. Campbell Power Plant, eastern Lakc Michigan, 1977. University of Michigan, Great Iakes Research Division, Special Report 65, Ann Arbor, Michigan, USA.

$\mathrm{Jude}_{1}$, D. J., G. R. Heufelder, H. T. Tin, N. A. Auer, S. A. Klinger, P. J. Schneeberger, 'I. L. Re'Tecki, C. P. Madenjian, and P. J. Rago. 1979. Adult and juvenile fish and ichthyoplanktor in the vicinity of the J. H. Campbell Power Plant, eastern Lake Michigan, 1978. University of Michigan, Great Lakes Research Division, Special Report 76, Ann Arbor, Michigan, USA.

Jude, D. J., F. J. Tesar, J. A. Dork III, I. J. Miller, P. J. Rago, And D. J. Stewart. 1975. Inshore Lake Michigan fish populations near the Donald C. Cook Nuclear Power Plant 1973. University of Michigan, Greal Lakes Research Division, Special Report 52, Ann Arbor, Michigan, USA.
Jude $_{2}$, D. J., F. J. Tesar, J. C. Tomlinson, T. J. MilLer, N. J. Thurber, G. G. Godun, and J. A. Dorr III. 1979. Inshore Iake Michigan fish populations near the D. C. Cook Nuclear Power Plant during preoperational years-1973, 1974. University of Michigan, Great Lakes Research Division, Special Report 71, Ann Arbor, Michigan, USA.

Lippson, A. J., ANd R. L. Moran. 1974. Manual for identification of early developmental stages of fishes of the Potomac River estuary. Environmental Technology Center, Martin Marietta Corporation, Baltimore, Maryland, USA.

Magliente, S. H., D. A. Tomljanovich, J. H. Heuer, S. Vigander, AND M. N. Smith. 1978. Investigations on the protection of fish larvae at water intakes using fine-mesh screening. Impingement-release concept: laboratory study of a single-entrance, double-exit, vertical traveling screen concept. Pages 66-7l in R. K. Sharma and J. B. Palmer, editors. Larval exclusion systems for power plant cooling water intakes. Argonne National Laboratory, Argonne, Illinois, USA.

Magnuson, J. L., and L. L. Smith. 1963. Some phases of the life history of the trout-perch. Ecology 44:83-95.

Murray, L. S., and T. S. Jinnette. I978. Survival of dominant estuarine organisms impinged on fine-mesh traveling screens at the Barney M. Davis Power Station. Pages 79-88 in R. K. Sharma and J. B. Palmer, editors. Larval exclusion systems for power plant cooling water intakes. Argonne National Laboratory, Argonne, Illinois, USA.

Mussalli, Y. G., E. P. Taft, and P. Hofmann. 1978. Biological and engineering considerations in the fine-screening of small organisms from cooling water intakes. Pages 107-124 in R. K. Sharma and J. B. Palmer, editors. Larval exclusion systems for power plant cooling water intakes. Argonne National Laboratory, Argonne, Illinois, USA.

Norden, C. R. 1961. The identification of larval yellow perch, Perca flavescens and walleye, Stizostedion vitreum. Copeia 1961:282-288.

OAk Ridge National Laboratory. 1979. Alternative screening devices at Indian Point units 2 and 3, Bowline Point, and Roseton generating stations (joint testimony of G. F. Cada, J. B. Cannon, and D. W. Lee). Oak Ridge National Laboratory, Oak Ridge, I'ennessee, USA.

Sameoto, D. D. 1971. The distribution of herring (Clupea harengus L.) larvae along the southern coast of Nova Scotia with some observations on the ecology of herring larvae and the biomass of macrozooplankton on the Scotian Shelf. Fisheries Research Board of Canada T echnical Report 252.

ToEtz, D. W. 1966. The change from endogenous to exogenous sources of energy in bluegill sun- 
fish larvae. Investigations of Indiana Lakes and Streams 7:115-146.

Tomljanovich, D. A., J. H. Heuer, and C. W. VOIGHTLAN DER. 1977. Investigations on the protection of fish larvae at water intakes using fine-mesh screening. Tennessee Valley Authority, Division of Forestry, Fisheries, and Wildlife Development, Technical Note B22, Norris, Tennessee, USA.

United States Environmental Protection AgEnCY. 1976. Development document for best technology available for the location, design, con- struction, and capacity of cooling-water intake structures for minimizing adverse environmental impact. Report EPA-440/1-76-015-a, Washington, District of Columbia, USA.

Wanc, J. C. S., And R. J. Kernehan. 1979. Fishes of the Delaware estuaries: a guide to early life histories. EA Communications, Ecological Analysts, Towson, Maryland, USA. 